\title{
The Pigovian Tax on Capital-Intensive Industries
}

\author{
資本集約産業に対するピグー税
}

Yuuki Maruyama

\begin{abstract}
Government intervention in the market and industrial policy tend not to be considered good. However, as can be seen from the Cobb-Douglas production function, capital has the effect of increasing the marginal productivity of labor, and the effect is greater in industries with high labor share (laborintensive industries). For this reason, if a Pigovian tax is imposed on capital-intensive industries, some capital will move to labor-intensive industries and workers' wages will increase. This paper uses a two-sector model to analyze the optimal Pigovian tax rate that will maximize the income of workers. It shows that the optimal Pigovian tax rate is higher in countries with higher productivity in capitalintensive industries and have more capital and less population.
\end{abstract}

政府による市場介入や産業政策は一般によくないとされている。しかし、コブ・ダグラス型生産関数を見 ても分かるように、資本には労働の限界生産性を高める効果があり、その効果は労働分配率の高い産業

（労働集約産業）ほど大きい。そのため、資本集約産業にピグー税を課すと、労働集約産業に資本が多く 投入されるようになり、労働者の賃金は増加することになる。今回は二部門モデルを用いて、労働者の総 収入を最大化できるような最適ピグー税率について分析する。資本の量の多い国・人口の少ない国・資本 集約産業の生産性が高い国ほど、最適なピグー税の税率は高いことが示される。

\section{1 序論}

一般に産業政策は自由市場に介入する良くないものであるとされている。政府は経済活動に介入せず、 市場に任せることこそが国民の効用を高めることにつながるといわれることが多い。実際、発展途上国 の経済政策へのアドバイスの方針であるワシントンコンセンサスでも、政府は産業活動に極力介入せず、 市場に任せることが経済成長に有用とされている。今回の論文では労働者の所得を高めるためには政府 が介入すべき事項もあることを示す。

資本と労働は補完性がある生産要素であり、片方が増えることでもう片方の限界生産性は上昇する。代 表的な生産関数であるコブ・ダグラス型生産関数においてもそのように扱われている。また、同じことで はあるが、資本と労働はそれぞれ単独で生産を行うよりも、共同で生産を行うほうが生産量は多くなる。 つまり、資本と労働は互いに外部経済の関係にあるということであり、労働者の限界生産性を最大化す るためには、資本から労働への外部経済性を最大限に活用寸る必要がある。労働集約産業は少ない資本 で多くの外部性を生み出すことができるのに対し、資本集約産業は多くの資本を消費するにも関わらず 
生み出される外部性は少ない。よって、労働者の限界生産性を最大化するためには労働集約産業を優遇 する必要がある。方法としては、産業政策やピグー税などが考えられる。今回のモデルでは、ピグー税を 採用して分析する。

今回のモデルにおいては資本集約産業に対してピグー税をかける。その税収は労働者に均等に分配さ れるとする。つまり、より高い税をかけるほど資本が労働集約産業に多く集まり労働者の賃金は高まる が、その分税収は減り労働者への再分配額は減ることになる。賃金額と再分配額を合わせた労働者の総 収入を最大化する税率について分析する。

\section{2 モデル}

二部門モデルとし、生産した財は消費せずに全て輸出する（貿易によって得た利益で購入する輸入品の みを消費すると考えて問題ない)。小国の仮定を導入し、財は同じ価格でいくらでも売ることができると する。また、資本集約産業は資本のみを生産要素とし、労働集約産業は資本と労働の 2 つを生産要素と する。労働者の人口は $L$ と、労働者は全員、労働集約産業で労働を行うこととする。生産関数はコブ・ ダグラス型関数を用いる。資本集約産業の資本所得にのみ税率 $t$ のピグー税をかけ、その税収は労働者に 均等に再分配されるとする。労働者の総収入は賃金額と再分配額を合わせた額となる。資本は両産業間 で自由に移動可能とし、両産業で利子率は均衡する。

産業 1 を資本集約産業とし、産業 2 を労働集約産業とする。両産業の生産関数はコブ・ダグラス型生産 関数とし、それぞれの労働分配率を 0 と $\beta$ とする $(0<\beta \leq 1$ とする)。よって、生産関数は

$$
\begin{aligned}
& Y_{1}=A_{1} K_{1} \\
& Y_{2}=A_{2} L^{\beta} K_{2}^{1-\beta}
\end{aligned}
$$

となる。また、各財の世界市場での価格はそれぞれ $P_{1}, P_{2}$ とする。

資本の総量は一定なので、 $K_{1}+K_{2}=K$

また、両産業間で利子率は均衡するので、 $(1-t) P_{1} A_{1}=(1-\beta) P_{2} A_{2} L^{\beta} K_{2}^{-\beta}$

労働者の総収入 (効用) $U$ は賃金と再分配額の和なので、

$$
\begin{aligned}
U & =t P_{1} Y_{1}+\beta P_{2} Y_{2} \\
& =t P_{1} A_{1} K_{1}+\beta P_{2} A_{2} L^{\beta} K_{2}^{1-\beta}
\end{aligned}
$$

この式に(1)と(2)を代入し、 $K_{1}$ と $t$ を消去すると

$$
U=\left\{P_{1} A_{1}-(1-\beta) P_{2} A_{2} L^{\beta} K_{2}^{-\beta}\right\}\left(K-K_{2}\right)+\beta P_{2} A_{2} L^{\beta} K_{2}^{1-\beta}
$$

となる。これを $K_{2}$ で微分すると

$$
\frac{\partial U}{\partial K_{2}}=(1-\beta) P_{2} A_{2} L^{\beta} K_{2}^{-\beta}-P_{1} A_{1}+\beta(1-\beta) P_{2} A_{2} L^{\beta} K_{2}^{-\beta-1}\left(K-K_{2}\right)+\beta(1-\beta) P_{2} A_{2} L^{\beta} K_{2}^{-\beta}
$$

労働者の総収入を最大化するような $K_{2}$ の值を求めるために、 $\frac{\partial U}{\partial K_{2}}=0$ とすると、

$$
\frac{1}{K_{2}^{\beta}}+\frac{\beta K}{K_{2}^{\beta+1}}=\frac{P_{1} A_{1}}{(1-\beta) P_{2} A_{2} L^{\beta}} \quad \text { となる }
$$


ここで、 $\frac{K_{2}}{K}=k_{2}$ とすると、

$$
\frac{1}{k_{2}^{\beta}}+\frac{\beta}{k_{2}^{\beta+1}}=\frac{P_{1} A_{1} K^{\beta}}{(1-\beta) P_{2} A_{2} L^{\beta}}
$$

(3)の左辺は $k_{2}$ についての単調減少関数であるため、この式は唯一つの解を持つ。労働者の総収入を最大 化するためには、 $k_{2}$ が(3)を満たすようにすればよい（この $k_{2}$ の解が 1 よりも大きくなってしまう場合 は、最適な $k_{2}$ の值は 1 ということになり、資本は全て労働集約産業に投入すべきということになる)。 また、(2)に(3)を代入すると、

$$
t=\frac{\beta}{k_{2}+\beta}
$$

となる。よって、最適な $t$ の值は正であることが分かる。つまり、政府は産業選択を市場に任せるよりも、 ピグー税を用いて産業選択に介入する方が良いということになる。

また、最適税率の規定要因についても分析を行う。(3)と(4)の式から定性的に分かることは、 $A_{1}, K の$ 值が 大きいほど、 $A_{2}, L$ 值が小さいほど、最適な $t$ の值は高くなるということである。

このメカニズムについて述べる。資本の総量 $K$ が大きい場合や労働者人口 $L$ が小さい場合は、労働集約 産業における資本の限界生産性の逈減が大きく、資本家はより多くの資本を資本集約産業に投下寸るこ とになる。そのため、ピグー税による賃金増加の余地は大きく、高いピグー税が望ましい。また、資本集 約産業の生産性 $A_{1}$ が高い場合や労働集約産業の生産性 $A_{2}$ が低い場合などについても、資本家にとって 資本集約産業に資本を多く投下寸るインセンティブが高い。産業間資本配分の是正のため、この場合に ついても高いピグー税が望ましいわけである。

\section{3 考察}

プレビッシュ・シンガー命題などに基づき、発展途上国では政府によって資本集約産業が振興される場 合が多く存在する。確かに、GDP を上昇させることを目標とするのであれば、資本集約産業は適してい る場合もあるかもしれない。しかし、資本集約産業は貴重な資本を多く消費するわりに、労働者への外部 経済性が少なく、賃金の上昇にはあまり貢献しない。たいていの場合、労働者の賃金はほとんど上がら ず、資本家の所得の上昇ばかりが起こる。もし、GDPの上昇ではなく労働者の賃金を上げることを目標 とするならば、労働集約産業を振興すべきと考えられる。この場合は、ワシントンコンセンサスのように 完全に市場に任せるよりも、むしろ政府がピグー税や産業政策などの方法で介入するほうが良い。

ただ、もし国に借入制約がないならば、産業選択については市場に任せるべきかもしれない。今回のモ デルは閉鎖経済のモデルであり資本の総量は一定であるとしたが、資本流入が起こるのであれば、資本 集約産業と労働集約産業はどちらも同時に発展させることができる。この場合は政府の介入は最小限が 良いであろう。しかし多くの場合、発展途上国には借入制約があり、今回の閉鎖経済のモデルと同じく外 部からの資本の流入が難しいという特徽がある。そうであれば、有限の資本を労働集約産業に振り分け、 資本から労働者への外部性を最大化することが、労働者にとって望ましいと考えられる。 


\section{4 補遺}

このモデルでは資本集約産業にピグー税を課すという課税方法を考察したが、現実の経済においては各 産業の資本集約度を測定していくのは困難である。実際に行うのであれば、雇用人数に応じて企業にピ グー補助金を支払うという形で行う方が実施しやすいと考えられる。もし、そのピグー補助金のための 税収を法人税の増税によって賄うことにするなら、ピグー税を実施する場合と実質的に同じ結果が得ら れる。

\section{参考文献}

Conesa, J. C., Kitao, S., \& Krueger, D. (2009). Taxing capital? Not a bad idea after all!. American Economic Review, 99(1), 25-48.

Correia, I. H. (1996). Should capital income be taxed in the steady state?. Journal of Public Economics, 60(1), 147-151.

Jones, L. E., Manuelli, R. E., \& Rossi, P. E. (1997). On the optimal taxation of capital income. journal of economic theory, 73(1), 93-117.

Judd, K. L. (1985). Redistributive taxation in a simple perfect foresight model. Journal of public Economics, 28(1), 59-83. 